\title{
Aktualitások a gyógyszer okozta állcsontelhalás primer és szekunder prevenciójának stratégiájában az evidenciák és a nemzetközi ajánlások tükrében
}

\author{
Vereb Tamás dr. - Janovszky Ágnes dr. - Mucsi Marietta dr. \\ Piffkó József dr. - Seres László dr. \\ Szegedi Tudományegyetem, Általános Orvostudományi Kar, Szent-Györgyi Albert Klinikai Központ, \\ Arc-, Állcsont- és Szájsebészeti Klinika, Szeged
}

Bevezetés: A multifaktoriális, nem teljesen tisztázott patomechanizmusú, gyógyszer okozta állcsontelhalás kezelése napjainkban is nagy kihívást jelent a maxillofacialis sebészek és fogorvosok, valamint az onkológiai és oszteológiai gyógyszert felíró kezelőorvosok számára.

Célkitüzés: Közleményünkben célul tűztük ki, hogy az aktuális szakirodalom áttekintését követően bemutassuk a változásokat a gyógyszer okozta állcsontelhalások patogenezisének, rizikótényezőinek, klinikai megjelenési formáinak, illetve a megelőzési és az új terápiás lehetőségeknek a tekintetében. Az elérhető nemzetközi ajánlások összehasonlításán, a nem sebészi és a sebészi, valamint a stádiumspecifikus kezelési módok evidenciaalapú bemutatásán túl a különböző orvosi-fogorvosi diszciplinákat érintő specifikumok bemutatására is törekszünk.

Módszer: Az elmúlt 5 évben - az egyre növekvő számú betegségorientált adatbázisnak köszönhetően - a szakirodalomban megnőtt a szisztematikus szakirodalmi áttekintések (systematic reviews), ajánlások és metaanalízisek száma; ezek áttekintését és összehasonlító elemzését végeztük el a kitûzött célok vonatkozásában.

Eredmények: Az American Association of Oral and Maxillofacial Surgeons munkacsoportjának legutóbbi ajánlása óta eltelt 4 évben is számos új gyógyszerhatástani csoport került a klinikusok látókörébe mint osteonecrosist indukáló potenciális ágens, így a betegség nómenklatúrája tovább cizellálódott, a betegcsoportok tovább specifikálódtak. A rizikóbetegek köre kiszélesedett, új betegpopulációknak (reumatológiai-oszteológiai betegek, immunszupprimáltak, transzplantáltak, új onkológiai 'target' [célzott] terápiában részesülők) kell a súlyos mellékhatás kialakulásával számolniuk.

Következtetés: Noha a betegcsoport kezelésében számos kérdés továbbra is nyitva áll, a korábbi empirikus kezelési formák helyett egyre erősebb evidenciákon alapuló, egyénspecifikus, stádiumadaptált terápiás megoldások körvonalazódnak.

Orv Hetil. 2020; 161(6): 214-223.

Kulcsszavak: gyógyszer okozta állcsontelhalás, 'target' terápia, antireszorptív terápia, antiangiogén terápia, biszfoszfonát, denoszumab

\section{Current evidence-based approaches and international guidelines in primary and} secondary prevention strategies of medication-related osteonecrosis of the jaws

\footnotetext{
Introduction: The presumably multifactorial pathomechanisms of medication-related osteonecrosis of the jaws have not been fully elucidated so far. Management of this rare but serious side effect is a real challenge and requires a multidisciplinary approach.

Aim: The aim of the authors was to take stock of our present knowledge about the pathogenesis, risk factors, clinical manifestations and the possibilities of prevention and treatment in the medication-related osteonecrosis of the jaws. In addition, the available international guidelines are compared and the evidence-based, stage-specific conservative and adjuvant therapeutic approaches are also reviewed, having regard to special aspects of medical and dental care.
} 
Method: In the last 5 years - due to the increasing number of disorder-oriented database - the number of available systematic reviews, recommendations and meta-analyses has escalated significantly which we reviewed and compared. Results: Since the last Position Paper published by the taskforce of the American Association of Oral and Maxillofacial Surgeons, novel pharmacological groups with the potential to induce osteonecrosis have come in the clinical scope, further elaborating the nomenclature of the disease and further specifying patient groups. The sphere of patients at risk has broadened and novel patient groups (rheumatologic-osteological, immunosuppressed, transplanted or oncological patients treated with monoclonal antibody, known as 'target therapy') are expected to develop this serious side effect.

Conclusion: Although a number of issues are still open regarding the treatment of the disorder, evidence-based, individualized, stage-adapted therapeutic approaches have replaced the previous empirical treatment.

Keywords: medication-related osteonecrosis of the jaw, target therapy, antiresorptive therapy, antiangiogenic therapy, bisphosphonates, denosumab

Vereb T, Janovszky Á, Mucsi M, Piffkó J, Seres L. [Current evidence-based approaches and international guidelines in primary and secondary prevention strategies of medication-related osteonecrosis of the jaws]. Orv Hetil. 2020; 161(6): 214-223

(Beérkezett: 2019. szeptember 11.; elfogadva: 2019. október 30.)

\begin{abstract}
Rövidítések
AAOMS $=$ (American Association of Oral and Maxillofacial Surgeons) Amerikai Arc-, Állcsont- és Szájsebészek Egyesülete; ARONJ $=$ (antiresorptive agent-related osteonecrosis of the jaws) antireszorptív szer okozta állcsontelhalás; $\mathrm{AR}=($ antiresorptive) antireszorptív; BRONJ = (bisphosphonate-related osteonecrosis of the jaws) biszfoszfonát okozta állcsontelhalás; CTIBL $=$ (cancer treatment-induced bone loss) onkológiai kezelés kiváltotta csontvesztés; CTLA4 = (cytotoxic T-lymphocyte-associated protein 4) citotoxikus T-lymphocyta-asszociált protein-4; $\mathrm{DM}=$ diabetes mellitus; DRONJ = (denosumabrelated osteonecrosis of the jaws) denoszumab okozta állcsontelhalás; ESWT = (extracorporeal shock wave therapy) testen kívül gerjesztett lökéshullámmal történő terápia; $\mathrm{HBO}=$ hiperbárikus oxigénterápia; Li-ESWT $=($ low-intensity ESWT $)$ alacsony intenzitású ESWT; LLLT = (low-level laser therapy) alacsony energiájú lézerrel történő kezelés; MiONJ $=($ mixed osteonecrosis of the jaws) kevert okú állcsontelhalás; MOTESZ = Magyar Orvostársaságok és Egyesületek Szövetsége; MRONJ $=$ (medication-related osteonecrosis of the jaws) gyógyszer okozta állcsontelhalás; mTOR $=$ (mammalian target of rapamycin) a rapamicin célpontja emlősökben; NPWT $=$ (negativepressure wound therapy) alacsony nyomású sebkezelés; OT = ózonterápia; PRF $=$ (platelet-rich fibrin) vérlemezkékben gazdag fibrin; PRGF = (platelet-rich growth factor) vérlemezkékben gazdag növekedési faktor; PRP $=$ (platelet-rich plasma) vérlemezkékben gazdag plazma; RA = rheumatoid arthritis; RANKL $=$ a receptoraktivátor nukleáris faktor kappa-B ligandja; TKI = tirozin-kináz-inhibitor; VEGF = (vascular endothelia growth factor) vascularis endothelialis növekedési faktor
\end{abstract}

A gyógyszer okozta állcsontelhalás első publikált esetei 2003-ban váltak ismertté a szakirodalomban [1]. Mivel ezek az esetek az onkológiai és oszteológiai (osteoporosis, rheumatoid arthritis, Paget-kór) betegek terápiájában 'arany standardnak' számító biszfoszfonátkezeléssel álltak összefüggésben, a kórképet BRONJ-nak (bisphosphonate-related osteonecrosis of the jaws) nevezték el. A biszfoszfonátkezelés az osteoclastaktivitás irreverzibilis gátlásával antireszorptív hatást fejt ki a csontokra, és rendkívül hatékonyan csökkenti a patológiás csontfájdalmakat, a skeletalis események (patológiás törés) létrejöttét, a tumor intraossealis növekedését, illetve a tumor indukálta hypercalcaemiát.

Az Amerikai Arc-, Állcsont- és Szájsebészek Egyesülete (American Association of Oral and Maxillofacial Surgeons - AAOMS) munkacsoportjának első hivatalos nemzetközi ajánlása is ezt a nómenklatúrát használta [2]. 2009-et követően a szakirodalomban megszaporodtak a nem biszfoszfonát hatóanyaggal összefüggésben álló állcsontelhalások, így 2014-ben az AAOMS módosította szakmai ajánlását mind a nevezéktan, mind a betegség definíciójának tekintetében, amely ma már „gyógyszer okozta állcsontelhalás"-ként (medication-related osteonecrosis of the jaw - MRONJ) hivatkozik erre a kórállapotra [3] (1. táblázat).

Az AAOMS ajánlása szerint a MRONJ kórképének súlyosság szerint 5 stádiuma állapítható meg:

Rizikócsoport: tünetmentes betegek, osteonecrosist kiváltó ágens használatával az anamnézisben.

0. stádium: atípusos klinikai és radiológiai eltérések (kisugárzó arcfájdalom, fogvesztés, a trabecularis csontszerkezet megváltozása) klinikailag igazolható osteonecrosis nélkül.

I. stádium: denudált, necroticus csontfelszín vagy szondázható fistula, lokális gyulladás nélkül.

II. stádium: denudált, necroticus csontfelszín vagy szondázható fistula, gyulladásos kísérő tünetek megjelenésével (fájdalom, erythema, pus), az alveolaris régióra lokalizált radiológiai eltérésekkel.

III. stádium: a II. stádium és a következő tünetek legalább egyike: a processus alveolarison túlterjedő osteo- 
1. táblázat

A nevezéktan és a definíció változásai az Amerikai Arc-, Állcsontés Szájsebészek Egyesülete (AAOMS) szerint, 2009-2014

\begin{tabular}{ll}
\hline $\begin{array}{l}\text { A biszfoszfonát okozta állcsont- } \\
\text { elhalás (BRONJ) definíciója - } \\
\text { AAOMS, 2009 }\end{array}$ & $\begin{array}{l}\text { A gyógyszer okozta állcsontelhalás } \\
\text { (MRONJ) definíciója - } \\
\text { AAOMS, 2014 }\end{array}$ \\
\hline $\begin{array}{l}\text { 1. Jelenleg is zajló vagy korábbi } \\
\text { biszfoszfonátkezelés }\end{array}$ & $\begin{array}{l}\text { 1. Jelenleg is zajló vagy korábbi } \\
\text { antireszorptív vagy antiangio- } \\
\text { gén kezelés }\end{array}$ \\
$\begin{array}{ll}\text { 2. Több mint } 8 \text { hete fennálló } \\
\text { denudált csontfelszín a }\end{array}$ & $\begin{array}{l}\text { 2. Tëbb mint } 8 \text { hete fennálló } \\
\text { denudált csontfelszín vagy } \\
\text { maxillofacialis régióban }\end{array}$ \\
$\begin{array}{l}\text { intra- és/vagy extraoralis } \\
\text { fistulanyilás a maxillofacialis } \\
\text { régióban }\end{array}$ \\
$\begin{array}{l}\text { 3. Megelőzó regionális } \\
\text { (fej-nyaki) radioterápia vagy } \\
\text { (fej-nyaki) radioterápia hiánya }\end{array}$ & $\begin{array}{l}\text { igazolt metasztatikus folyamat } \\
\text { hiánya az állcsontokban }\end{array}$ \\
\end{tabular}

necrosis, patológiás törés, extra- vagy intraoralis fistula (1. ábra).

Az onkoterápiában a modern kezeléseknek köszönhetően jelentős élettartam-növekedés és életminőség-javulás vált elérhetővé a páciensek számára. A hosszan tartó hormonablatiós kezelések (például emlő- és prosztatacarcinoma) hozadékaként azonban a vizsgálatok csontsürűség-csökkenésről és csonttömegveszteségről számoltak be (cancer treatment-induced bone loss - CTIBL) [4]. Ezen - az onkológusok számára jól ismert - mellékhatások kezelésére a biszfoszfonátok mellett más, kedvezőbb farmakokinetikájú antireszorptív szerek kerültek forgalomba.

A humán monoklonális antitest denoszumab a biszfoszfonátoknál is erőteljesebb antireszorptív készítmény, amely az egyik legerősebb, csontbontást előidéző biológiai tényezőnek, a receptoraktivátor nukleáris faktor kappa-B ligandjának (RANKL) inhibitora. A RANKL gátlá-

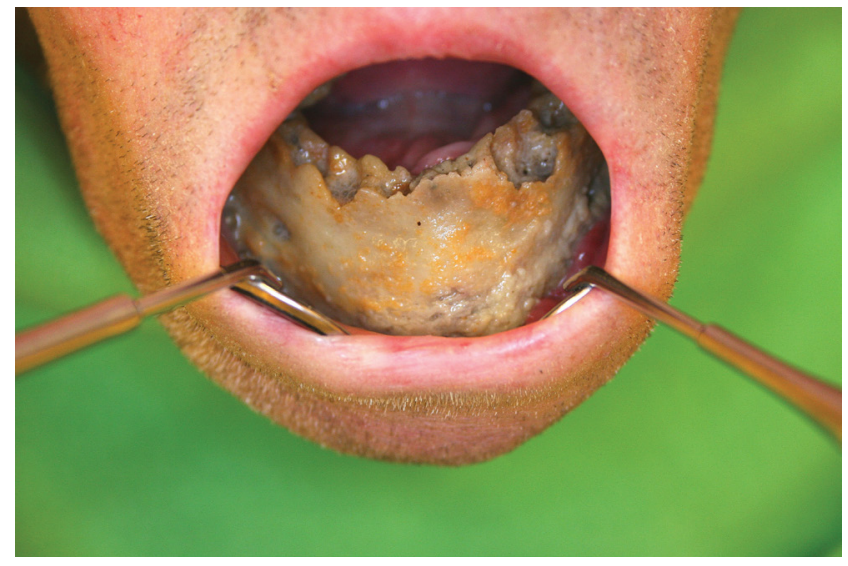

1. ábra $\quad$ Prosztatatumor biszfoszfonátkezelése után kialakult súlyos, a processus alveolarison túlterjedő III. stádiumú osteonecrosis

sával csökken az osteoclastok érése és aktivitása, ennek eredményeképpen pedig a csontok törékenysége. Az alapbetegségre gyakorolt kiváló hatása mellett az új szer is erőteljes szájüregi mellékhatásokat okozhat. A szakirodalom a denoszumabkezeléssel összefüggő állcsontelhalást DRONJ-ként (denosumab-related osteonecrosis of the jaw) definiálja [5].

A biszfoszfonátok és a denoszumab használatára az alapbetegség időben hosszú lefolyása miatt sokszor együtt vagy egymás után kerül sor ugyanannál a páciensnél, így a közös használat esetén kumulatív hatások is kialakulhatnak, melyek jelentősen megnövelik az osteonecrosisok kialakulási valószínúségét. A szakirodalom esetenként MiONJ-ként (mixed osteonecrosis of the jaws) hivatkozik ezekre az esetekre. A biszfoszfonát, RANKL-gátló vagy közös használat miatt kialakult állcsontelhalásokra összefoglalóan az antireszorptív szer okozta osteonecrosis (ARONJ - antiresorptive agent-re-

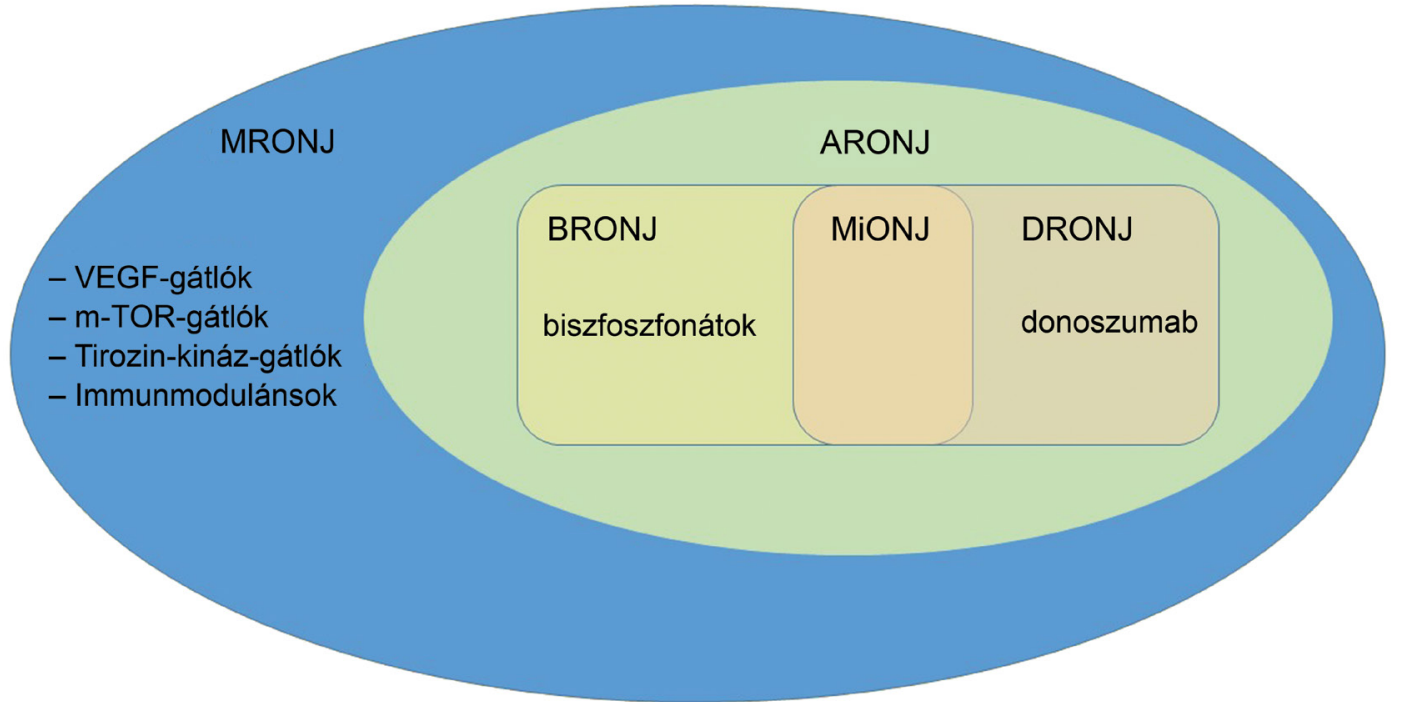

2. ábra Gyógyszer okozta állcsontelhalások csoportosítása

ARONJ = antireszorptív szer okozta állcsontelhalás; BRONJ = biszfoszfonát okozta állcsontelhalás; DRONJ = de $\neg$ noszumab okozta állcsontelhalás; MiONJ = kevert okú állcsontelhalás; MRONJ = gyógyszer okozta állcsontelhalás; $\mathrm{mTOR}=$ a rapamicin célpontja emlősökben; VEGF $=$ vascularis endothelialis növekedési faktor 
lated osteonecrosis of the jaws) definícióval hivatkozik a szakirodalom [6].

Az utóbbi évtizedben a biológiai 'target' (célzott) terápiák körében végbement robbanásszerü fejlődés további nonantireszorptív gyógyszerhatástani csoportokkal összefüggésben vezetett állcsontelhalások észleléséhez. A leggyakrabban a bevacizumab [7], aflibercept [8] VEGF- (vascular endothelial growth factor) gátlókkal és különböző tirozin-kináz-gátlókkal - szunitinib [9], szorafenib [10], kabozantinib [11] - kapcsolatban ismertek esetek, de leírtak már necrosist a CTLA4- (cytotoxic T-lymphocyte-associated protein 4) gátló ipilimumab [12], valamint az anti-mTOR (mammalian target of rapamycin) ágens temszirolimusz [13] és everolimusz [14] esetén is (2. ábra).

A kiszélesedett indikációs területek, a megnövekedett betegszám, valamint a különböző támadáspontú hatóanyagcsoportok közötti nem várt interakciók és szinergista hatások (biszfoszfonát - denoszumab, biszfoszfonát - VEGF-gátlók, denoszumab - VEGF-gátlók) következtében a MRONJ incidenciája és prevalenciája egyaránt növekvő tendenciát mutat. Számos szerző egyetért abban, hogy a közölt szakirodalmi adatok inkább alábecsülik a valós incidenciát és prevalenciát [15].

A betegség incidenciája az alkalmazott hatóanyag(ok) típusa, a beadási mód (iv./per os), a kumulatív dózis, az alap- és kísérő betegségek, valamint a kiegészítő gyógyszeres terápiák függvényében széles határok között változik. A kialakulás valószínúsége az elérhető magyar és nemzetközi publikációk alapján a különböző betegpopulációkban több nagyságrendes eltérést is mutathat $[16,17]$. Az állcsontelhalás kialakulásának valószínúsége szempontjából az aktuális szakirodalom megkülönböztet „low-risk” (alacsony rizikójú) és „high-risk” (magas rizikójú) pácienseket. Általánosságban alacsonyabb az osteonecrosis kialakulásának kockázata a jóindulatú alap-
2. táblázat |A gyógyszer okozta állcsontelhalás (MRONJ) rizikóbecslési kritériumai

\begin{tabular}{ll}
\hline 'Low-risk' beteg & 'High-risk' beteg \\
\hline Szisztémás: & Szisztémás: \\
Benignus (oszteológiai) & Malignus alapbetegség \\
alapbetegség & Kombinált/konkomitáns AR + \\
Egyszerü AR vagy VEGF-terápia & VEGF-terápia \\
Oralis gyógyszer-adminisztráció & Intravénás gyógyszer-adminiszt- \\
Alacsony kumulatív dózis, rövid & ráció \\
kezelési idő & Magas kumulatív dózis, hosszú \\
Kísérő betegség hiánya & kezelési idő \\
(DM, RA) & Kísérố betegség jelenléte \\
Egyéb gyógyszeres kezelés & (DM, RA) \\
hiánya & Egyéb gyógyszeres kezelés \\
Lokális: & (szteroid-, immunterápia) \\
Nincs megelőző MRONJ az & Lokális: \\
anamnézisben & Megelóző MRONJ az anamné- \\
Jó pácienscompliance & zisben \\
Jó szájhigiéné & Rossz pácienscompliance \\
Fogon megtámasztott pótlás/ & Rossz szájhigiéné \\
nincs fogpótlás & Nyálkahártyán/rosszul \\
& támaszkodó fogpótlás
\end{tabular}

$\mathrm{AR}=$ antireszorptív $; \mathrm{DM}=$ diabetes mellitus; $\mathrm{RA}=$ rheumatoid arthritis; VEGF = vascularis endothelialis növekedési faktor

betegség, az oralis bevitel, az alacsony kumulatív gyógyszerdózis, a kísérő betegségek hiánya, a konkomitáns gyógyszeres terápia hiánya, a jó szájhigiéné, illetve a megfelelö betegcompliance eseteiben. A MRONJ kialakulását elősegítő faktorok közé soroljuk a malignus alapbetegséget, az intravénás gyógyszerbevitelt, a magas kumulatív dózist, a hosszan tartó gyógyszerhasználatot, különböző támadáspontú hatóanyagok konkomitáns alkalmazását, a rossz szájhigiénét, a rosszul illeszkedő fogpótlást és a nem megfelelő compliance-t $[18,19]$ (2. táblázat).

A kórkép patomechanizmusa máig nem teljesen tisztázott, feltételezhetően multifaktoriális eredetű, a külön-

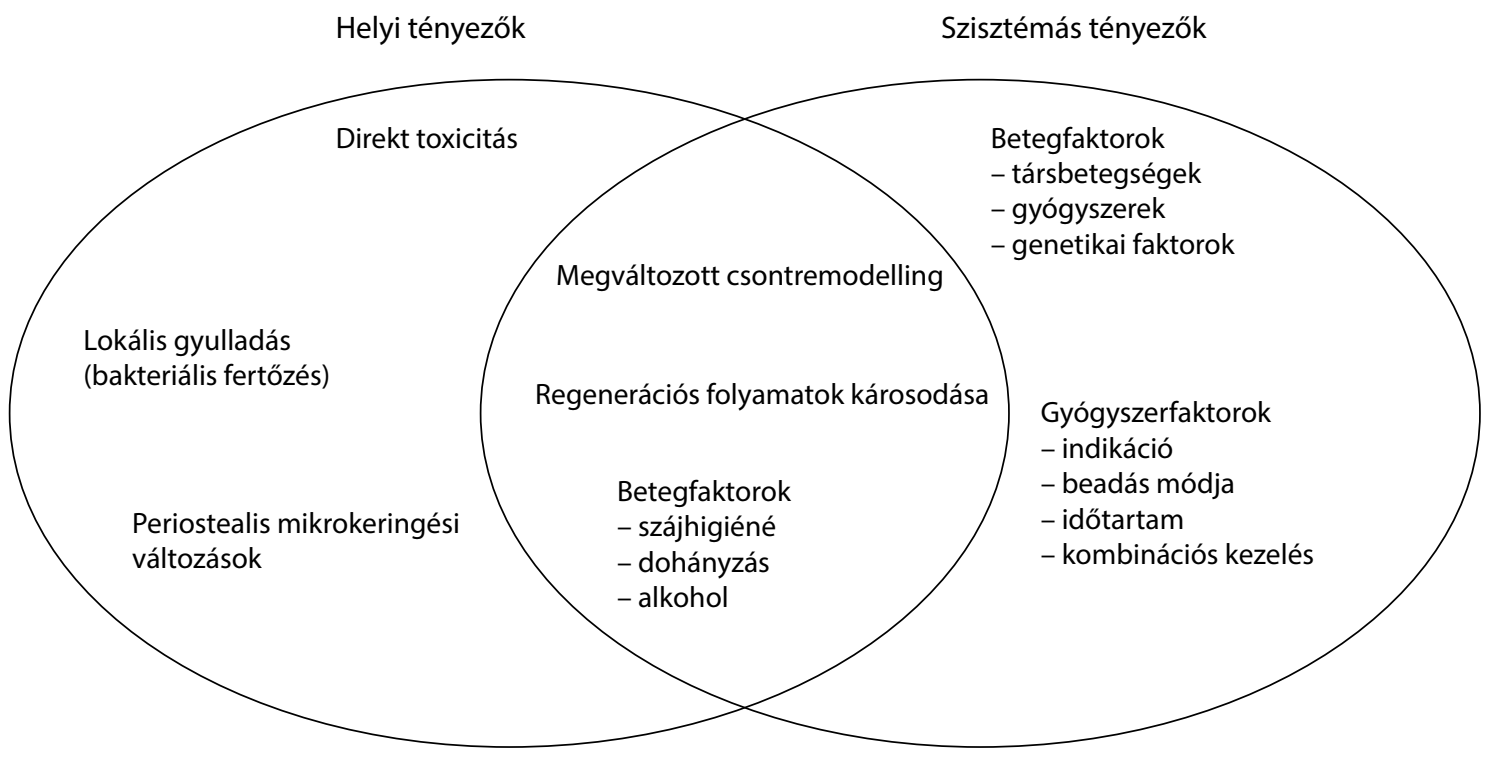

3. ábra

| A gyógyszer okozta állcsontelhalás etiopatogenezisében szerepet játszó tényezők 
böző biokémiai támadáspontokon és jelátviteli útvonalakon ható gyógyszerek és a külső környezetből érkező triggerfaktorok interakciójának eredőjeként fejlődhet ki. A lehetséges patofiziológiai tényezők lehetnek: az antireszorptív szerek hatására megváltozott csontanyagcsere (osteoclastaktivitás-gátlás miatti csontfelszívódás, „oversuppression”), angio(neo)genezisgátlás, celluláris toxicitás, veleszületett vagy szerzett immunhiányos állapotok miatt csökkent immunvédelem, állandó mikrotraumák az állcsontokban és lokális gyulladásos faktorok jelenléte [20] (3. ábra).

A diagnózis felállítása és a 'staging' a klinikai és a radiológiai tünetek alapján történik. A részletes anamnézis elengedhetetlen a MRONJ definíciós kritériumok teljesülésének és az esetleges kizáró kritériumok meglétének vagy hiányának igazolásához. A radiológiai vizsgálatok alapvető célja az állcsontelhalás kiterjedésének megítélése, az individuális sebészi kezelési tervezés elősegítése (a reszekciós szélek meghatározása, rekonstrukciós beavatkozások megtervezése), az esetek utánkövetése és dokumentálása, valamint a prognózis megítélése [21]. Differenciáldiagnosztikai szempontból az osteomyelitistől, az osteoradionecrosistól és a csontáttéttől különítendő el. Tekintettel a patogenezis nem teljesen tisztázott voltára és annak sokszínűségére, oki terápia jelenleg nem áll rendelkezésre. A kezelési lehetőségek magukban foglalják a kórkép prevencióját, a progresszió késleltetését vagy megakadályozását, valamint a kialakult - különböző stádiumú - elváltozások stádiumfüggő és stádiumfüggetlen konzervatív, sebészi és kiegészítő terápiáját [22].

\section{Módszer}

Az elmúlt 5 évben - az egyre növekvő számú betegségorientált adatbázisnak köszönhetően - megnőtt a szisztematikus szakirodalmi áttekintések, szakmai ajánlások és metaanalízisek száma. Közleményünk célja a PubMeden és a Cochrane Library-n keresztül elérhető nemzetközi (angol és német nyelvü) és hazai szakirodalmi adatok evidenciaszintjét is figyelembe véve, azok áttekintését és összehasonlító elemzését követően, a mindennapi gyakorlatot és betegellátást segítő vezérfonal felvázolása gyakorló orvos/fogorvos kollégák számára.

\section{Eredmények}

A 2014. évi AAOMS-ajánlás megjelenése óta eltelt 5 évben majdnem 500 új publikáció jelent meg a gyógyszer okozta állcsontelhalások témakörében, melyekből közel 100 összefoglaló közlemény volt. Mivel a pontos kóroki

3. táblázat |A gyógyszer okozta állcsontelhalás (MRONJ) prevenciós lehetőségei a nemzetközi szakmai társaságok javaslatai alapján

\begin{tabular}{|c|c|c|}
\hline $\begin{array}{l}\text { Társaság } \\
\text { (az ajánlás éve) }\end{array}$ & $\begin{array}{l}\text { Prevenció } \\
\text { Alacsony rizikó }\end{array}$ & $\begin{array}{l}\text { Prevenció } \\
\text { Magas rizikó }\end{array}$ \\
\hline \multirow[t]{2}{*}{$\begin{array}{l}\text { American Association of Oral and } \\
\text { Maxillofacial Surgeons (2014) }\end{array}$} & \multicolumn{2}{|c|}{$\begin{array}{l}\text { - Fogászati szürés és szanáció az antireszorptív } \pm \text { antiangiogén kezelés megkezdése előtt, részletes } \\
\text { betegtájékoztatás } \\
\text { - 'Drug holiday’ kapcsán nincs evidencia, hogy csökkentené a MRONJ rizikóját }\end{array}$} \\
\hline & & $\begin{array}{l}\text { - A lehető legkonzervatívabb fogászati megoldás választása } \\
\text { - Rendszeres fogászati szűrés } \\
\text { - A panaszok korai felismerése és diagnózis felállítása }\end{array}$ \\
\hline $\begin{array}{l}\text { British Association of Oral and } \\
\text { Maxillofacial Surgeons (2017) }\end{array}$ & \multicolumn{2}{|c|}{$\begin{array}{l}\text { - 0,2\%-os klórhexidin szájfertótlenító alkalmazása } 4 \times 10 \mathrm{ml} / \text { die min. } 14 \text { napon keresztül } \\
\text { - metronidazol } 200 \mathrm{mg} 3 \times 15 \text { napon keresztül vagy amoxicillin + klavulánsav } 250 / 125 \mathrm{mg} 3 \times 1 \\
5 \text { napon keresztül } \\
\text { - } 6 \text { héten belül ismételt kontroll a varratszedést leszámítva }\end{array}$} \\
\hline $\begin{array}{l}\text { Arbeitsgemeinschaft der } \\
\text { Wissenschaftlichen Medizinischen } \\
\text { Fachgesellschaften (2018) }\end{array}$ & \multicolumn{2}{|c|}{$\begin{array}{l}\text { - Az invazív beavatkozások minimalizálása és a konzervatívabb beavatkozások előtérbe helyezése } \\
\text { - A perioperativ időszakban parenteralis antibiotikumkezelés az invazív beavatkozások során } \\
\text { - Atraumatikus beavatkozás, az éles csontszélek elsimítása } \\
\text { - Primer sebzárás } \\
\text { - Rendszeres kontroll }\end{array}$} \\
\hline $\begin{array}{l}\text { Japanese Society of Oral and } \\
\text { Maxillofacial Surgeons (2016) }\end{array}$ & \multicolumn{2}{|c|}{$\begin{array}{l}\text { - Alacsony klinikai evidencia a 'drug holiday' kapcsán, nem is találtak különbséget antireszorptív kezelés } \\
\text { esetén az incidenciában } \\
\text { - A sebgyógyulást negatívan befolyásolja, így a per os készítmények elhagyása a teljes sebgyógyulásig } \\
\text { (kb. } 2 \text { hónap) szóba jöhet, mérlegelve a patológiás törés esélyét } \\
\text { - Perioperatív antibiotikumvédelem, antibakteriális hatású szájfertőtlenítők alkalmazása javasolt } \\
\text { - Atraumatikus sebészi technika, az éles csontszélek elsimítása } \\
\text { - A mútéti terület primer zárása mucoperiostealis lebennyel }\end{array}$} \\
\hline $\begin{array}{l}\text { Canadian Association of Oral and } \\
\text { Maxillofacial Surgeons (2008) }\end{array}$ & $\begin{array}{l}\text { - Instruálás, motiválás, megfelelő szájhigiéné } \\
\text { fenntartása } \\
\text { - Góckutatás és fogászati szanáció a kezelés } \\
\text { megkezdése előtt } \\
\text { - A 'drug holiday' megfontolandó elektív } \\
\text { invazív beavatkozás előtt }\end{array}$ & $\begin{array}{l}\text { - Instruálás, motiválás, megfelelő szájhigiéné fenntartása } \\
\text { - Góckutatás és fogászati szanáció a kezelés megkezdése } \\
\text { előtt } \\
\text { - Életmódváltás (a dohányzás abbahagyása, az alkoholbe- } \\
\text { vitel csökkentése) } \\
\text { - Invazív beavatkozást követően a sebgyógyulásig javasolt } \\
\text { az antireszorptív terápia felfüggesztése (3-6 hónap) }\end{array}$ \\
\hline
\end{tabular}


tényező jelenleg is kérdéses, az antireszorptív és/vagy egyéb onkológiai kezeléseket indikáló kezelöorvosok számára a legfontosabb teendők a kezelés megkezdése előtti prevenció és a kezelés alatt kialakult elváltozás mihamarabbi felismerése, az alábbiak szerint.

A Magyar Arc-, Állcsont- és Szájsebészeti Társaság kezdeményezésére, a Magyar Orvostársaságok és Egyesületek Szövetsége (MOTESZ) által 2014-ben összehívott „A biszfoszfonátok által indukált állcsont-osteonecrosisok megelőzése és kezelése" konszenzuskonferencián megfogalmazott ajánlás szerint a kezelőorvos a tervezett gyógyszeres kezelés elött a tájékozott beleegyezés elveit figyelembe véve járjon el [23]. Mivel az állcsontelhalás rizikóját csak minimalizálni lehet, teljesen megszüntetni nem, a páciens felvilágosítása és együttmúködésének elnyerése nélkülözhetetlen. Jelenleg a kórkép megelőzésének leghatékonyabb eszköze a jó szájhigiéné fenntartása és a rendszeres fogászati utánkövetés.

A tervezett gyógyszeres kezelés megkezdése előtti 3 hónapban átfogó, minden részletre kiterjedő fogászati klinikai és radiológiai vizsgálat javasolt, melyet követően bármilyen szükséges fogászati beavatkozás elvégezhető és elvégzendő. Az antireszorptív és/vagy antiangiogén kezelés megkezdése előtt sort kell keríteni a beteg fogászati szanációjára, melynek során a konzerváló fogászati módszerekkel megőrizhető fogak ellátása mellett az irreparábilis vagy rossz prognózisú fogak eltávolítása mindenképpen elvégzendő. Amennyiben a tervezett kezelés megkezdése előtt - bármely tényező miatt - a dentális szanáció nem volt kivitelezhető, úgy a pácienst a szükséges fogászati beavatkozások elvégzésekor minden esetben rizikóbetegnek kell tekinteni. A gyógyszeres kezelés megkezdése utáni időszakban a nemzetközi szakmai társaságok ajánlásai ezen időszakra a 3. táblázatban ismertetett kezelési irányelveket fogalmazzák meg a rizikóbetegekre vonatkozóan [24-27].

Mivel az állcsontelhalás valószínúsége alapján a szakirodalom az eddig ismert kockázati tényezőket figyelembe véve megkülönböztet alacsony és magas rizikójú pácienseket, a kezelés megkezdése előtt az anamnesztikus adatok, a klinikai vizsgálatok és a tervezett kezelési módok alapján tanácsos a kezelést indikáló szakorvosnak rizikóbecslést végeznie [28] (4. ábra).

Az antireszorptív vagy antiangiogén terápia megkezdését követően fontos hangsúlyozni a rendszeres fogászati szűrés és kontrollvizsgálatok jelentőségét, ugyanis ezzel biztosítható adott fogászati eltérések minél korábbi stádiumban történő felismerése, a szükséges noninvazív vagy kevésbé invazív, kisebb rizikóval járó beavatkozások kivitelezhetősége. Magas rizikójú betegeknek sűrúbben, legalább 3 havonta, alacsony rizikójú betegeknek pedig 6 havonta ajánlott a fogászati és sztomatoonkológiai kontrollvizsgálat elvégzése. A kontrollvizsgálatok alkalmával mindenképp érdemes rákérdezni atípusos tünetek, bizonytalan, tompa fájdalom jelenlétére, valamint kivehető fogpótlással rendelkező betegek esetében a nyálkahártyadecubitusok meglétére.

\section{1) Kezelés kumulatív dózisa}

2) Kezelés időtartama

\section{3) MRONJ-rizikófaktor(ok)}

Megelöző biszfoszfonát- vagy denoszumab-kezelés

Kortikoszteroid / kemoterápia / VEGF-gátló használata (korábban vagy aktuálisan)

> Rossz szájhigiéné, lokális gyulladás jelenléte, rosszul illeszkedő fogpótlás

> Kísérőbetegségek jelenléte (hematológiai, immunbiológiai, diabetes mellitus)

$>$ Dohányzás

\section{Alacsony MRONJ-rizikó}

Korábbi kezelés nem volt/<3 év
Magas öszdózis

4. ábra

A MRONJ-kockázat becslése Nicolatou-Galitis szerin

MRONJ = gyógyszer okozta állcsontelhalás 
Ezen rizikócsoport bármilyen fogászati kezelését MRONJ-betegek ellátásában jártas maxillofacialis szakembernek vagy ilyen betegek ellátására szakosodott centrumnak kell(ene) indikálnia és felügyelnie, hogy a páciens állapotában bekövetkező változásokat minél gyorsabban felismerhessék. Összefoglalva elmondható, hogy a noninvazív fogászati beavatkozások nem igényelnek antibiotikumprofilaxist, megfelelő elővigyázatossággal biztonsággal elvégezhetők, akár a fogászati alapellátás keretei között. A sebészi beavatkozások csak és kizárólag antibiotikumvédelemben végezhetők el a rizikóbesorolásnak megfelelő módon, az erre felkészült maxillofacialis sebészeti központokban.

A rizikóbetegek kezelése minden esetben individuális kezelési terv alapján kell, hogy történjen, az összes kockázati tényező szigorú megítélésével, a kísérő betegségek, a gyógyszerelés figyelembevételével, a 'cost/benefit' (költség/haszon) arány preoperatív értékelésével, a lehető legjobb hosszú távú prognózis elérése érdekében.

$\mathrm{Az}$ antireszorptív vagy antiangiogén kezelésben részesülő, alacsony vagy magas rizikójú páciensek vagy manifeszt MRONJ-betegek fogászati ellátásában a konzerváló fogászati, endodontiai és protetikai kezeléseknek elsőbbséget kell élvezniük. A konzerváló fogászati és endodontiai beavatkozások biztonsággal kivitelezhetők, nem igényelnek antibiotikumvédelmet. Az endodontiai kezeléseket a szakirodalom az invazív dentoalveolaris beavatkozások alternatívájaként ajánlja, a MRONJ kialakulási rizikójának csökkentésére [29].

A különböző mértékű foghiánnyal rendelkező betegek protetikai rehabilitációja során a fogon rögzített fix pótlások preferálandók; ha csak a nyálkahártyán támaszkodó kivehető pótlás készítése jön szóba, úgy alábélelést kell alkalmazni, a nyomásasszociált recidívák elkerülése céljából. Átadás után szoros kontroll (havonta) javasolt, hogy a viselés okozta tünetek akutan korrigálhatók legyenek [30].
Az antireszorptív kezelés alatt álló betegek esetében a fogszabályozó kezelésnek abszolút kontraindikációja nem áll fenn. A fogmozgatás lehetséges, a kezelés kimenetele azonban nem számítható ki előre, különösen magas rizikójú betegnél. A megváltozott csontmetabolizmus, a szklerotikus csontállomány és a mellékhatásprofil miatt gyakrabban észlelhető gyökérfelszívódással, valamint lassabb mozgatási sebességgel és következményesen hoszszabb kezelési időtartammal lehet számolni [31].

A parodontológiai kezelések kapcsán, a dentális sínezést leszámítva, minden beavatkozás kapcsán vérzéssel és bakteriális expozícióval lehet számolni, így a kezelések megkezdése előtt antibiotikumprofilaxis szükséges [32].

Az invazív dentoalveolaris sebészeti beavatkozások (például fogeltávolítás, alveolusplasztika), szintén elvégezhetők antibiotikumprofilaxis alkalmazásával, habár a MRONJ kialakulásának rizikónövekedésével számolni kell. Törekedni kell arra, hogy kizárólag a rossz prognózisú vagy menthetetlen fog eltávolítására kerüljön sor, ne a protetikai terv határozza meg az eltávolítandó fogak számát. Ezekben az esetekben mindig mérlegelendő a tervezett beavatkozás 'cost/benefit' aránya. Fontos hangsúlyozni, hogy amennyiben alternatív megoldás lehetséges (például gyökérkezelés, gyökérsapkázás), a konzervatív ellátás preferálandó.

A rizikócsoportokba tartozó betegek dentális implantációjának és preprotetikai sebészi ellátásának tekintetében dinamikusan változnak az irányelvek és a szemléletek. A legújabb nemzetközi szakirodalmi adatok alapján az alacsony rizikójú betegek esetében nem észleltek magasabb MRONJ-incidenciát, így ebben a betegcsoportban perioperatív antibiotikumvédelemben kivitelezhetók ezek a beavatkozások, azonban a magas rizikójú betegek kapcsán továbbra sem rendelkezünk nagy esetszámú, multicentrikus tanulmányokkal, így ebben a betegcsoportban kontraindikált ezen beavatkozások elvégzése.

A csontpótlással vagy arcüregemeléssel járó preprotetikai beavatkozások nagy körültekintést igényelnek, és

4. táblázat | Fogászati beavatkozások kivitelezhetősége és a MRONJ-kockázat összefüggése

\begin{tabular}{|c|c|c|c|}
\hline \multirow[t]{2}{*}{ A fogászati beavatkozás típusa } & \multirow{2}{*}{$\begin{array}{l}\text { Onkológiai betegek } \\
\text { Magas rizikó }\end{array}$} & \multicolumn{2}{|c|}{ Osteometabolicus betegek } \\
\hline & & Alacsony rizikó & Közepes rizikó \\
\hline \multicolumn{4}{|l|}{ Nem sebészi beavatkozások: } \\
\hline - Konzerváló fogászati kezelés & Indikált & Indikált & Indikált \\
\hline - Endodontiai kezelés & Indikált & Indikált & Indikált \\
\hline - Fogszabályozó kezelés & Lehetséges & Lehetséges & Lehetséges \\
\hline - Parodontológiai kezelés (nem sebészi) & Indikált & Indikált & Indikált \\
\hline - Fogpótlástani kezelés & Lehetséges & Lehetséges & Lehetséges \\
\hline \multicolumn{4}{|l|}{ Sebészi beavatkozások: } \\
\hline - Dentoalveolaris sebészi kezelés & Indikált & Indikált & Indikált \\
\hline - Preprotetikai sebészi kezelés & Kontraindikált & Lehetséges & Lehetséges \\
\hline - Implantológiai kezelés & Kontraindikált & Lehetséges & Lehetséges \\
\hline - Parodontológiai kezelés (sebészi) & Indikált & Indikált & Indikált \\
\hline
\end{tabular}

MRONJ = gyógyszer okozta állcsontelhalás 
magas rizikójú esetekben nem javasolhatók. A megfelelő csontgyógyulás előfeltétele ugyanis a recipiens hely jó vérellátása, az osteoclast-osteoblast egyensúly megléte, a csontremodelling zavartalan volta, melyek antireszorptív kezelés esetén egyaránt gátoltak [33].

Di Fede és mtsai 2018-ban publikáltak egy tanulmányt, melyben a különböző fogászati diszciplinák által végezhető beavatkozásokat osztályozták a MRONJ kialakulásának rizikója szempontjából [34] (4. táblázat).

\section{Adjuváns terápiás lehetőségek}

A MRONJ kezelésének nem sebészi módszerei nem kizárólag a gyógyszeres terápiára korlátozódnak, különböző munkacsoportok számos alternatív kezelési móddal próbáltak javulást előidézni [35].

A növekedésifaktor-koncentrátumok (PRP/PRF/ PRGF) használatának betegségre gyakorolt hatásait vizsgálva Del Fabbro és mtsai metaanalízisükben arra a következtetésre jutottak, hogy ezen biológiailag aktív autológ anyagoknak a sebészi kezeléssel egyidejű alkalmazása - az egyelőre kisszámú evidencia ellenére - előnyös a posztoperatív szövődmények elkerülésében és a MRONJ-recidívák, valamint az egyéb mellékhatások csökkentésében [36].

Sacco és mtsai a 2019-ben publikált - ez idáig egyetlen - 'systematic review'-ban az ózon- és a hiperbárikus oxigénterápia (OT és HBO) MRONJ-ra gyakorolt hatásait vizsgálták. A dolgozatban kiemelik, hogy döntően alacsony evidenciájú vizsgálatokból nyert adatokkal dolgoztak; a szerzők az esetek egy részénél javulásról számoltak be, ugyanakkor néhány esetben a kezelés alatt progressziót is észleltek. Jelenleg nem létezik meggyóző bizonyíték sem az ózon-, sem a hiperbárikus oxigénterápia egymással és/vagy placebóval szembeni szuperioritását illetôen [37].

$\mathrm{Az}$ alacsony energiájú lézerrel történő kezelés (LLLT - low-level laser therapy) alkalmazásával stimulálható a lágyszöveti regeneráció, az angioneogenezis, ezáltal gyorsulhat a gyógyulási folyamat. Az eljárás hatékonyságát a MRONJ kezelésében Weber és mtsai 2016-ban megjelent közleményükben vizsgálták. A vizsgált szakirodalom szerint mind a konzervatív kezeléshez (lokális antimikrobiális terápia és szisztémás antibiotikum), mind pedig a MRONJ sebészi kezelése után alkalmazott LLLT szignifikáns javulást eredményezett a komplett vagy részleges sebgyógyulásban, a gyógyulási időben, a posztoperatív gyulladásban és fájdalomban is a kontrollcsoportokkal összehasonlítva. A szerzők a korai stádiumú BRONJ eseteiben 'arany standard' kezelésnek ajánlják a kombinált perioperatív antibiotikum, minimálinvazív sebészet és posztoperatív LLLT kombinációt, azzal a megjegyzéssel, hogy további vizsgálatok szükségesek a lézer alkalmazásának specifikációit illetően (a lézer típusa, kimeneti energia, energiasűrűség, alkalmazási idő, távolság és frekvencia) [38].
A testen kívül gerjesztett lökéshullámmal történő terápiát (Li-ESWT - low-intensity extracorporeal shock wave therapy) régóta sikerrel alkalmazzák a szexuális medicinában erektilis diszfunkció és az ortopédiában combfejnecrosis és gyulladásos elváltozások kezelésében. Használata során fájdalomcsillapító, gyulladáscsökkentő, szövetregeneráló és neovascularisatiós hatásokat figyeltek meg, melyek valószínúleg a vascularis endothelialis növekedési faktor (VEGF) fokozott expressziója által jönnek létre. Fej-nyaki alkalmazhatósága és hatásossága jelenleg vizsgálatok tárgyát képezi [39].

Az alacsony nyomású sebkezelés (NPWT - negativepressure wound therapy) számos extraoralis területen kiváló eredménnyel használható krónikus vagy fertőzött sebek kezelésében. A fej-nyaki régióban történő alkalmazása azonban - a régió anatómiai bonyolultsága miatt számos nehézségbe ütközik. A NPWT sikeres intraoralis alkalmazási lehetőségeiről ez idáig csak esettanulmányok jelentek meg az irodalomban [40].

Összefoglalóan elmondható, hogy a foghúzást követően, illetve a MRONJ stádiumspecifikus terápiáját kiegészítő, adjuváns terápiás lehetőségek célja a csont és a környező lágyrészek regenerációjának fokozása, valamint a gyulladásos jelátviteli mechanizmusok gátlása. E kezelési modalitások hatékonyságát illetően azonban a szakirodalomban a különböző szerzók sokszor egymásnak ellentmondó adatokat közölnek, a hatásosságuk tekintetében bizonyított, magas evidenciájú ismeretekkel ez idáig nem rendelkezünk.

\section{Megbeszélés}

A gyógyszer okozta állcsontelhalás számos onkológiai és oszteológiai konzervatív kezelésnek az életminőséget potenciálisan súlyosan rontó mellékhatása, különösen az antireszorptív és antiangiogén hatásmechanizmusú szerekkel összefüggésben. Noha előfordulási gyakoriságát tekintve ritka kórképról van szó, az incidencia és a prevalencia értékeinek növekedésére lehet számítani a kezelt páciensek számának növekedésével, a túlélési mutatók javulásával, a potensebb szerek megjelenésével és hatóanyag-interakciók létrejöttével.

A kórkép pontos és összetett patomechanizmusa máig vizsgálatok tárgyát képezi, így oki terápia nem áll rendelkezésre, ezért a gyógyszert használó betegeknél rendkívül fontos a primer prevenció a MRONJ rizikójának minimalizálása érdekében. A kockázat csökkentésével nemcsak egy fájdalmas és nehezen tolerálható mellékhatástól szabadíthatjuk meg a pácienst, hanem az alapkezelés előnyeinek maximalizálását is biztosíthatjuk.

A páciens vezetése multidiszciplináris feladat, amelyben a kezelőorvos feladata - az adekvát terápia indikálásán túl - az individuális rizikóbecslés is.

A kezelőorvosnak felelőssége van abban, hogy az állcsontelhalás kockázatát rejtő terápia megkezdése előtt a beteget a fogadására felkészült arc-, állcsontsebészeti vagy fogászati centrumba irányítsa a szükséges fogászati 
restaurációk elvégzése céljából. A fogorvosoknak a kezelés megkezdése elôtt kulcsszerepük van a MRONJ prevenciójában, hiszen a betegek felvilágosításával, a profilaktikus dentális kezelések kivitelezésével, a megfelelő fogpótlások elkészítésével és a rendszeres utánkövetéssel csökkenthető a leghatékonyabban az állcsontelhalás kockázata.

A kezelés megkezdését követően a rizikópáciensek esetében ajánlott, hogy bármilyen fogászati kezelést a MRONJ-betegek ellátásában jártas, a diagnosztikus kritériumokat és a nemzetközi terápiás ajánlásokat jól ismerő maxillofacialis sebész szakember indikáljon/felügyeljen, aki a páciens állapotában bekövetkező változásokat gyorsabban fel tudja ismerni. Az antireszorptív kezelésben részesülő vagy MRONJ-ból gyógyult betegek esetén elsősorban a konzerváló fogászati és endodontiai kezelésnek van létjogosultága. Panaszmentes, magas rizikójú betegeknek 3 havonta, alacsony rizikójúaknak pedig 6 havonta ajánlott a fogászati-sztomatoonkológiai kontrollvizsgálat.

A kombinált antireszorptív és/vagy antiangiogén kezelések együttes vagy egymás utáni alkalmazása radikálisan növeli a MRONJ kockázatát, alacsonyabb kumulatív dózis után kialakulhat, a folyamat rapidabb progressziója várható, és rosszabb prognózisra lehet számítani. Manifeszt állcsontelhalás kialakulása esetén az alapbetegség valószínúleg meghatározza a MRONJ-betegek gyógyulási potenciálját/gyógyhajlamát.

Az állcsontelhalás diagnózisának felállításához, a stádiumbesoroláshoz és a megfelelő terápia kiválasztásához adekvát klinikoradiológiai 'staging' rendszer szükséges. Az evidenciák a stádiumspecifikus kezelési stratégiákat illetően jelenleg még nem erősek. Kezdeti stádiumú MRONJ (0-I. stádium) esetén a nem sebészi/konzervatív kezelés kedvezőbbnek tünik a kimenetel szempontjából. A kiterjesztett sebészi megoldások - debridement, sequestrectomia, necrectomia, sebészi reszekció - előrehaladott MRONJ (II-III. stádium) esetén kedvezőbb eredményt adnak, mint a konzervatív kezelés. A necroticus csont sebészi eltávolítása az ajánlások szerint bármilyen stádiumban kivitelezhető, de a gyógyulási eredmények széles skálán mozognak (I. st.: 0-100\%, II. st.: 52-100\%, III. st.: 50-100\%). A nehezen jósolható kimenetelű sebészi intervenciót ezért csak megfelelő performance-státuszú, jó compliance-û, életminőségükben súlyosan érintett betegek esetében, megfelelően felkészült ellátóhelyen javasolt elvégezni.

Noha az elmúlt másfél évtizedben a kórképról szerzett ismereteink jelentősen bővültek, sőt az utóbbi néhány évben a terápiával kapcsolatos evidenciaalapú tudásunk is gyarapodott, a kórkép kezelésében ez idáig sem a konzervatív, sem a sebészi megoldások nem vezettek megbízhatóan és kiszámíthatóan szignifikáns javuláshoz. Tekintettel arra, hogy a kórkép nemcsak a páciens életminőségét érintheti rendkívül negatívan, hanem a rekurráló, exacerbáló epizódok kezelésével az egészségügyi ellátórendszer érintett egységeinek költségvetésére is je- lentős terhet ró, az adekvát, evidenciaalapú oki terápia megtalálásáig a megfelelő megelőzési stratégiákra kell helyezni a hangsúlyt, amiben kiemelt szerepe van a kezelöorvosnak is.

A jövőben további jól tervezett vizsgálatok szükségesek, különösen az előrehaladott stádiumú betegek ideális kezelési protokolljának kialakításában.

Anyagi támogatás: A dolgozat elkészítése során a szerzők anyagi támogatásban nem részesültek.

Szerzôi munkamegosztás: V. T.: Irodalomkutatás, az adatbázis elkészítése, a végleges szöveg megírása. J. Á., M. M.: Irodalomkutatás, a végleges szöveg megírása. P. J.: Szakmai véleményezés. S. L.: Szakmai véleményezés, a végleges szöveg megírása. A cikk végleges változatát valamennyi szerző elolvasta és jóváhagyta.

Érdekeltségek: A szerzőknek nincsenek érdekeltségeik.

\section{Irodalom}

[1] Marx RE. Pamidronate (Aredia) and zoledronate (Zometa) induced avascular necrosis of the jaws: a growing epidemic. J Oral Maxillofac Surg. 2003; 61: 1115-1117.

[2] Ruggiero SL, Dodson TB, Assael LA, et al. American Association of Oral and Maxillofacial Surgeons position paper on bisphosphonate-related osteonecrosis of the jaws - 2009 update. J Oral Maxillofac Surg. 2009; 67(5_Suppl): 2-12.

[3] Ruggiero SL, Dodson TB, Fantasia J, et al. American Association of Oral and Maxillofacial Surgeons position paper on medication-related osteonecrosis of the jaw - 2014 update. J Oral Maxillofac Surg. 2014; 72: 1938-1956.

[4] Brufsky AM. Cancer treatment-induced bone loss: pathophysiology and clinical perspectives. Oncologist 2008; 13: 187-195.

[5] Kyrgidis A, Toulis KA. Denosumab-related osteonecrosis of the jaws. Osteoporos Int. 2011; 22: 369-370.

[6] Hellstein JW, Adler RA, Edwards B, et al. Managing the care of patients receiving antiresorptive therapy for prevention and treatment of osteoporosis: executive summary of recommendations from the American Dental Association Council on Scientific Affairs. J Am Dent Assoc. 2011; 142: 1243-1251.

[7] Guarneri V, Miles D, Robert N, et al. Bevacizumab and osteonecrosis of the jaw: incidence and association with bisphosphonate therapy in three large prospective trials in advanced breast cancer. Breast Cancer Res Treat. 2010; 122: 181-188.

[8] Mawardi H, Enzinger P, McCleary N, et al. Osteonecrosis of the jaw associated with ziv-aflibercept. J Gastrointest Oncol. 2016; 7: E81-E87.

[9] Soós B, Vajta L, Szalma J. Sunitinib and zoledronic acid induced osteonecrosis of the jaw. [Sunitinib és zoledronsav által indukált állcsont-osteonecrosis.] Orv Hetil. 2015; 156: 1865-1870. [Hungarian]

[10] Garuti F, Camelli V, Spinardi L, et al. Osteonecrosis of the jaw during sorafenib therapy for hepatocellular carcinoma. Tumori 2016; 102(2_Suppl): S69-S70.

[11] Marino R, Orlandi F, Arecco F, et al. Osteonecrosis of the jaw in a patient receiving cabozantinib. Aust Dent J. 2015; 60: 528531.

[12] Owosho AA, Scordo M, Yom SK, et al. Osteonecrosis of the jaw a new complication related to ipilimumab. Oral Oncol. 2015; 51: e100-e101. 
[13] Fusco V, Santini D, Armento G, et al. Osteonecrosis of jaw beyond antiresorptive (bone-targeted) agents: new horizons in oncology. Expert Opin Drug Saf. 2016; 15: 925-935.

[14] Yamamoto D, Tsubota Y, Utsunomiya T, et al. Osteonecrosis of the jaw associated with everolimus: a case report. Mol Clin Oncol. 2017; 6: 255-257.

[15] Galis B, Zajko J, Hirjak D, et al. Is the prevalence of the medication-related osteonecrosis of the jaws underestimated, evaluation in oncological and non-oncological disease. Bratisl Lek Listy 2017; 118: 724-731.

[16] Veszelyné Kotán E, Bartha-Lieb T, Parisek Z, et al. Database analysis of the risk factors of bisphosphonate-related osteonecrosis of the jaw in Hungarian patients. BMJ Open 2019; 9: e025600.

[17] Advisory Task Force on Bisphosphonate-Related Ostenonecrosis of the Jaws. American Association of Oral and Maxillofacial Surgeons position paper on bisphosphonate-related osteonecrosis of the jaws. J Oral Maxillofac Surg. 2007; 65: 369-376.

[18] McGowan K, McGowan T, Ivanovski S. Risk factors for medication-related osteonecrosis of the jaws: a systematic review. Oral Dis. 2018 ; 24 : $527-536$.

[19] Zurányi A, Vasziné Szabó E, Tóth Zs. Risk assessment of medication-related osteonecrosis of the jaw in general dental practice. [A gyógyszer által indukált állcsontnecrosis-kockázat mértékének meghatározása az általános fogorvosi gyakorlatban.] Orv Hetil. 2019; 160: 243-251. [Hungarian]

[20] Aghaloo T, Hazboun R, Tetradis S. Pathophysiology of osteonecrosis of the jaws. Oral Maxillofac Surg Clin North Am. 2015; 27: 489-496.

[21] Tsuchimochi M, Kurabayashi T. Symposium: Imaging modalities for drug-related osteonecrosis of the jaw, role of imaging in drug-related osteonecrosis of the jaw: an up-to-date review (secondary publication). Jpn Dent Sci Rev. 2019; 55: 1-4.

[22] Janovszky Á, Vereb T, Szabó A, et al. Current approaches for early detection and treatment of medication-related osteonecrosis of jaw. [Aktuális trendek a gyógyszer indukálta állcsontnecrosis korai felismerése és kezelési stratégiája terén.] Orv Hetil. 2014; 155: 1960-1966. [Hungarian]

[23] Prevention and therapy of bisphosphonate-induced mandibular osteonecrosis. [Felhívás. A Magyar Arc-, Állcsont- és Szájsebészeti Társaság kezdeményezésére, a Magyar Orvostársaságok és Egyesületek Szövetsége (MOTESZ). A biszfoszfonátok által indukált állcsont-oszteonekrózisok megelőzése és kezelése.] Fogorv Szle. 2014; 107: 106-107. [Hungarian]

[24] Khan AA, Morrison A, Hanley DA, et al. Diagnosis and management of osteonecrosis of the jaw: a systematic review and international consensus. J Bone Miner Res. 2015; 30: 3-23.

[25] Poxleitner P, Engelhardt M, Schmelzeisen R, et al. The prevention of medication-related osteonecrosis of the jaw. Dtsch Arztebl Int. 2017; 114: 63-69.

[26] Japanese Allied Committee on Osteonecrosis of the Jaw, Yoneda T, Hagino H, Sugimoto T, et al. Antiresorptive agent-related osteonecrosis of the jaw: Position Paper 2017 of the Japanese Allied Committee on osteonecrosis of the jaw. J Bone Miner Metab. 2017; 35: 6-19.

[27] Khan AA, Sándor GK, Dore E, et al. Canadian consensus practice guidelines for bisphosphonate associated osteonecrosis of the jaw. J Rheumatol. 2008; 35: 1391-1397.
[28] Nicolatou-Galitis O, Schiødt M, Mendes RA, et al. Medicationrelated osteonecrosis of the jaw: definition and best practice for prevention, diagnosis, and treatment. Oral Surg Oral Med Oral Pathol Oral Radiol. 2019; 127: 117-135.

[29] Moinzadeh AT, Shemesh H, Neirynck NA, et al. Bisphosphonates and their clinical implications in endodontic therapy. Int Endod J. 2013; 46: 391-398.

[30] Bata Zs, Vasziné Szabó E, Tóth Zs. Considerations of elderly patient's dental rehabilitation treated with bisphophonate. [A fogpótláskészítés szempontjai biszfoszfonáttal kezelt idôs páciens esetén.] Orv Hetil. 2018; 159: 2031-2036. [Hungarian]

[31] Zymperdikas VF, Yavropoulou MP, Kaklamanos EG, et al. Effects of systematic bisphosphonate use in patients under orthodontic treatment: a systematic review. Eur J Orthod. 2019; pii: cjz021.

[32] Yoneda T, Hagino H, Sugimoto T, et al. Bisphosphonate-related osteonecrosis of the jaw: position paper from the allied task force committee of Japanese Society for Bone and Mineral Research, Japan Osteoporosis Society, Japanese Society of Periodontology, Japanese Society for Oral and Maxillofacial Radiology, and Japanese Society of Oral and Maxillofacial Surgeons. J Bone Miner Metab. 2010; 28: 365-383.

[33] Stavropoulos A, Bertl K, Pietschmann P, et al. The effect of antiresorptive drugs on implant therapy: systematic review and meta-analysis. Clin Oral Impl Res. 2018; 29(Suppl 18): 54-92.

[34] Di Fede O, Panzarella V, Mauceri R, et al. The dental management of patients at risk of medication-related osteonecrosis of the jaw: new paradigm of primary prevention. Biomed Res Int. 2018; 2018: 2684924.

[35] Beth-Tasdogan NH, Mayer B, Hussein H, et al. Interventions for managing medication-related osteonecrosis of the jaw. Cochrane Database Syst Rev. 2017; 10: CD012432.

[36] Del Fabbro M, Gallesio G, Mozzati M. Autologous platelet concentrates for bisphosphonate-related osteonecrosis of the jaw treatment and prevention. A systematic review of the literature. Eur J Cancer 2015; 51: 62-74.

[37] Sacco R, Leeson R, Nissan J, et al. A systematic review of oxygen therapy for the management of medication-related osteonecrosis of the jaw (MRONJ). Appl Sci. 2019; 9: 1026.

[38] Weber JB, Camilotti RS, Ponte ME. Efficacy of laser therapy in the management of bisphosphonate-related osteonecrosis of the jaw (BRONJ): a systematic review. Lasers Med Sci. 2016; 31 : 1261-1272.

[39] Özkan E, Özkan TH. Effects of extracorporeal shock wave therapy in the maxillofacial surgery practice - a systematic review. Int J Health Sci (Qassim). 2019; 3: 186-195.

[40] Laimer J, Steinmassl O, Hechenberger M, et al. Intraoral vacuum-assisted closure therapy - a pilot study in medication-related osteonecrosis of the jaw. J Oral Maxillofac Surg. 2017; 75: 2154-2161.

(Vereb Tamás dr., Szeged, Kálvária sgt. 57., 6725 e-mail: vereb.tamas@med.u-szeged.hu)

A cikk a Creative Commons Attribution 4.0 International License (https://creativecommons.org/licenses/by/4.0/) feltételei szerint publikált Open Access közlemény, melynek szellemében a cikk bármilyen médiumban szabadon felhasználható, megosztható és újraközölhetö, feltéve, hogy az eredeti szerzỏ és a közlés helye, illetve a CC License linkje és az esetlegesen végrehajtott módositások feltüntetésre kerülnek. (SID_1) 